\title{
PREDIKSI KELULUSAN TEPAT WAKTU MENGGUNAKAN METODE C4.5 DAN $K-N N$ \\ (Studi Kasus : Mahasiswa Program Studi S1 Ilmu Farmasi, Fakultas Farmasi, Universitas Muhammadiyah Purwokerto)
}

\author{
Eko Purwanto $^{1}$, Kusrini ${ }^{2}$, Sudarmawan ${ }^{3}$ \\ ${ }^{123}$ Department of Informatics, University AMIKOM Yogyakarta, Jl. Ring Road Utara, Condong Catur, \\ Sleman, Yogyakarta, Central Java, 55283, Indonesia
}

\section{Informasi Makalah}

Dikirim, 14 Agustus 2019

Direvisi, 14 Oktober 2019

Diterima, 16 Oktober 2019

\section{Kata Kunci:}

Prediksi

Kelulusan tepat waktu

Mahasiswa

Algoritma

C. 45

K-NN

Seleksi mundur

Variabel

\section{INTISARI}

Profil kelulusan merupakan salah satu element penting bagi standar akreditasi perguruan tinggi. Profil kelulusan mencerminkan kinerja sistem penyelenggaraan pendidikan yang dianut dalam jangka waktu tertentu. Semakin baik profil kelulusan, semakin baik pula nilai akreditasinya. Untuk mewujudkan hal tersebut, prediksi kelulusan dapat dilakukan pada basis data akademik mahasiswa. Hal ini penting dilakukan untuk menelusuri dan mengelompokkan data historikal ke dalam data latih dan data uji, untuk selanjutnya digunakan untuk memprediksi kelulusan tepat waktu. Langkah ini penting untuk membantu menentukan kebijakan manajemen yang lebih baik dari proses pembelajaran. Untuk itulah kajian ini dilakukan untuk menganalisa penggunaan variabel-variabel tertentu untuk memprediksi kelulusan tepat waktu dengan menggunakan metode algoritma C.45 dan K-Nearest Neighbour (K-NN). Penambangan data dilakukan pada basis data akademik mahasiswa program studi Farmasi, Fakultas Farmasi, Universitas Muhammadiyah Purwokerto, dengan menambahkan beberapa variabel tertentu ke dalam proses penambangan data. Data kemudian diklasifikasikan ke dalam data latih dan data uji. Seleksi mundur digunakan untuk menyeleksi variabel yang paling baik dan berpengaruh terhadap set data. Kajian lebih jauh menunjukkan bahwa dengan menggunakan algoritma C.45 dan seleksi mundur, keakuratan kelulusan mencapai diatas $84.75 \%$. Hasil ini berbeda dari keakuratan yang ditunjukkan oleh algoritma K-NN dan seleksi mundur yang mencapai $89.14 \%$. Hasil ini memberikan manfaat yang penting bagi program studi untuk membuat arah kebijakan yang lebih baik guna meningkatkan kualitas pelayanan, terutama pelayanan proses pembelajaran.

\section{Keyword:}

Prediction

On-time graduation

Students

Algoryhtm

C. 45

K-NN

Backward selection

Variables

\begin{abstract}
The graduation profile is one of the key elements for the accreditation standard of higher education. It mirrors the performance of the applied educational system within a period of time. The better it is, the better the accreditation will be. In support of this, a graduation prediction may be conducted to the academic database of the students. It is of pivotal to trace and classify the historical data into the data training and data testing, thus, to predict the on time-graduation. The step is importantly done to help decide the better management of learning processes. This study was therefore done to analyse certain variables applied to predict the on time-graduation using the algorythms of C.45 and K-Nearest Neighbour (K-NN). The data mining was done to the academic database of the students of the Pharmacy study programme, Pharmacy Faculty, Muhammadiyah University of Purwokerto by adding certain variables into the process. The data was then classified into the data training and data testing. Backward selection was done to select the best and most influential variables for the dataset. The study further resulted that by using the algorhythm of C.45 and backward selection, the accuracy of the graduation reached $84.75 \%$. It is different from the acurracy the K-NN and backward selection showed that reached $89.14 \%$. The result confirmed that the KNN showed the better accuracy than the C.45. It considerably benefitted
\end{abstract}


the study programme to make better decisions on increasing the quality of services, in particular that of leraning processes.

\section{Korespondensi Penulis:}

Eko Purwanto

Department of Informatics, University AMIKOM Yogyakarta,

Jl. Ring Road Utara, Condong Catur, Sleman, Yogyakarta,

Central Java, 55283, Indonesia

\section{PENDAHULUAN}

Salah satu parameter penting dalam dunia pendidikan, baik dasar, menengah, maupun tinggi adalah tingkat kelulusan siswa dan atau mahasiswa. Bagi para siswa di pendidikan dasar dan menengah,kelulusan adalah bagian penting untuk melanjutkan pendidikan mereka ke jenjang yang lebih tinggi. Bagi seorang mahasiswa, kelulusan menjadi bagian penting dan awal dari karir dan bahkan kelanjutan untuk menuju ke jenjang yang semakin tinggi. Bagi perguruan tinggi, tingkat kelulusan mahasiswa menjadi salah satu aspek penting penilaian akreditasi. Hal ini seperti dijelaskan dalam Standar 3 pada Buku V Panduan Akreditasi Progam Studi yang dikeluarkan oleh Badan Akreditasi Nasional, tentang Kemahasiswaan dan Lulusan. Dalam standar ini, salah satu butir penilaian diambil dari profil mahasiswa dan lulusan yang mencakup di antaranya (dalam tahun) rerata jumlah mahasiswa, rerata masa studi, dan rerata Indeks Prestasi Kumulatif (IPK). Jika suatu program studi mimiliki rerata masa studi dan IPK yang baik, maka hal ini tentu akan berpengaruh pada institutional branding yang juga akan semakin baik. Sesuai acuan akreditasi, rerata masa studi yang baik adalah yang sesuai atau tepat waktu; sedangkan IPK yang baik adalah $\geq 3,00$.

Sehubungan dengan hal di atas, diperlukan suatu strategi untuk mempredikasi masa studi atau waktu kelulusan mahasiswa dari awal. Hal ini dimaksudkan untuk membantu mahasiswa meningkatkan kualitas belajarnya dan membantu program studi memperbaiki kualitas penyelenggaraan pendidikan. Dengan demikian, upaya untuk mencapai rerata masa studi tepat waktu dan menghindari drop-out serta meningkatkan mutu layanan pendidikan dapat terwujud.

Ketepatan masa studi juga menjadi hal penting bagi mahasiswa prodi S1 Ilmu Farmasi, Fakultas Farmasi, Universitas Muhammadiyah Purwokerto. Berdasarkan kurikulum prodi dan SNPT, persyaratan kelulusan ditentukan oleh total sks minimum yang harus ditempuh, yaitu 144 sks dan IPK minimum yaitu, 2,76. Ketepatan waktu lulusan adalah 4 tahun atau 8 semester. Dari data akademik yang diambil dari 5 tahun terakhir mahasiswa dengan status lulus yaitu angkatan 2010 hingga angkatan 2015, tren kelulusan menunjukkan pola yang fluktuatif, seperti terlihat pada gambar1 dan 2 berikut.

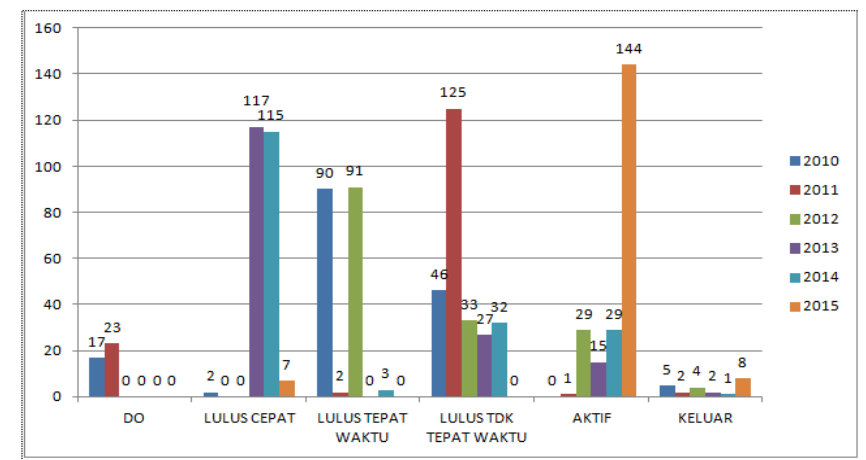

Gambar 1. Profil jumlah lulusan Program Studi S1 Ilmu Farmasi, Fakultas Farmasi, Universitas Muhammadiyah Purwokerto 5 tahun terakhir mahasiswa dengan status lulus (tahun masuk angkatan 2010-2015.) 


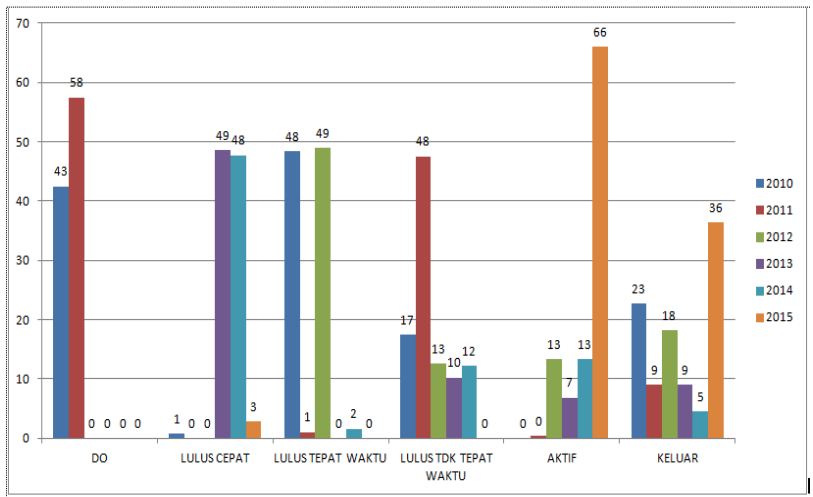

Gambar 2. Persentase profil lulusan Program Studi S1 Ilmu Farmasi, Fakultas Farmasi, Universitas Muhammadiyah Purwokerto 5 tahun terakhir mahasiswa dengan status lulus (tahun masuk angkatan 2010-2015.)

Pada kedua gambar di atas, diperoleh data bahwa persentase kelulusan tepat waktu (4 tahun) mahasiswa prodi S1 Ilmu Farmasi masih sangat rendah untuk 3 tahun terakhir, tetapi dua tahun terakhir sangat tinggi untuk lulus dengan cepat (kurang dari 4 tahun). Sementara itu, untuk data kelulusan tidak tepat waktu cenderung rendah pada 3 tahun terakhir. Hal ini menunjukkan bahwa data ini tidak beraturan karena didasarkan pada rasio jumlah mahasiswa yang masuk dan yang keluar (lulus), tidak didasarkan pada kualitas input, proses, dan kualitas luaran (output).

Untuk itulah penelitian ini akan dilakukan untuk mengetahui variabel-variabel penentu yang akan digunakan untuk memprediksi masa studi tepat waktu dan menentukan kebijakan yang lebih tepat untuk meningkatkan waktu kelulusan tepat dan cepat waktu dan mengurangi angka drop-out (DO) dan tidak tepat waktu. Penelitian ini akan dilakukan dengan data mining melalui algoritma C4.5 dan K-Nearest Neighbour $(K$-NN).

\section{LANDASAN TEORI}

\subsection{Data Mining}

[1] mendefinisikan data mining sebagai suatu kajian tentang pengumpulan, pembersihan, pemrosesan, analisis, dan pemerolehan beragam pengetahuan yang bermanfaat dari suatu data. Kajian ini berhubungan dengan domain permasalahan, aplikasi, formulasi dan representasi data yang ditemukan dalam aplikasi nyata. Dengan kata lain, "data mining" adalah "payung umum" ("broad umbrella") yang digunakan untuk mendeskripsikan keempat aspek berbeda ini dalam pemrosesan data [3] data mining sebagai kebutuhan yang sangat penting karena berhubungan dengan pergerakan dan pengumpulan data besar yang begitu cepat setiap harinya. Data mining juga dapat dikatakan sebagai evolusi teknologi informasi dari sistem pemrosesan file primitif menuju sistem basis data yang kuat dan canggih. Lebih jauh, data mining merujuk pada istilah "knowledge mining from data, knowledge extraction, data/pattern analysis, data archaeology, dan data dredging". Umumnya orang lebih mudah mengenalnya sebagai "knowledge discovery from data" atau KDD (penemuan pengetahuan dari data) [3].

Sementara itu, [4] menyebut data mining sebagai solusi permasalahan dengan menganalisa data yang sudah ada dalam basis data. Dengan demikian, ini juga disebut sebagai proses penemuan pola dalam basis data yang diharapkan dapat memberikan keuntungan secara ekonomis [4].

Berdasarkan pengertian di atas, data mining dapat disimpulkan sebagai:

a. Suatu kajian tentang proses pengolahan data

b. Suatu evolusi teknologi informasi

c. Suatu proses ekstraksi atau penambangan pengetahuan atau informasi dari basis data besar yang berguna untuk pengambilan keputusan di masa depan, memperkecil pengeluaran, dan memberikan keuntungan

Proses penemuan pengetahuan atau informasi dalam data mining dapat dilakukan dengan beberapa tahap, yaitu:

1 Data cleaning (untuk menghilangkan data yang mengganggu dan tidak konsisten)

2 Data integration (mengkombinasikan sumber-sumber data yang banyak/multiple)

3 Data selection (pengambilan data dari basis data yang relevan dengan tugas analisis)

4 Data transformation (data diubah dan dikonsolidasikan ke dalam bentuk-bentuk yang sesuai untuk ditambang melalui operasi agregasi dan ringkasan)

5 Data mining (proses penting mengekstraksi pola-pola data)

6 Pattern evaluation (mengidentifikasi pola-pola yang benar-benar menarik yang merepresentasikan pengetahuan berdasarkan "interestingness-measures") 
7 Knowledge representation (visualisasi dan teknik representasi pengetahuan yang telah ditambang kepada pengguna) [3].

Selanjutnya dapat dilihat dalam Gambar 3 di bawah ini.

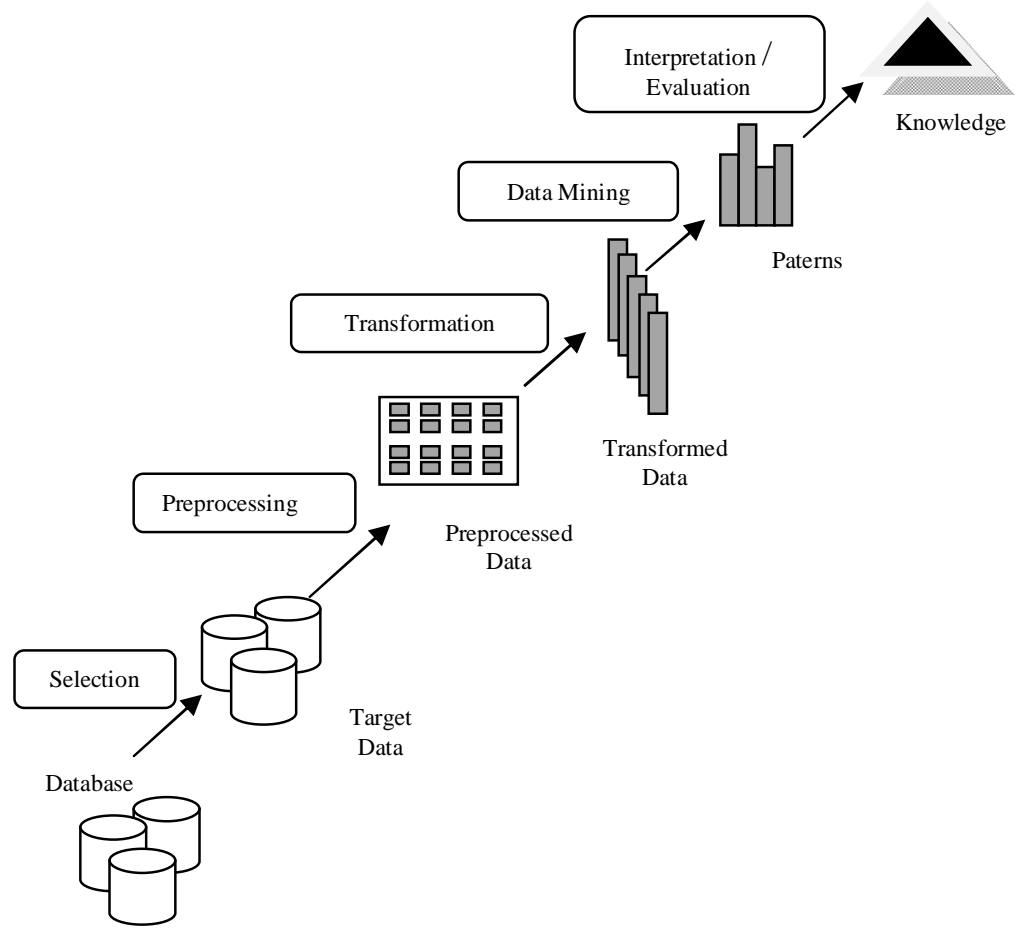

Gambar 3.Tahap-tahap ekstraksi informasi dari basis data.

Data mining dalam penelitian ini akan menggunakan algoritma C4.5 dan K-NN untuk memprediksi kelulusan tepat waktu mahasiswa prodi Farmasi Universitas Muhammadiyah Purwokerto Tahun Lulusan 2010-2015.

\section{2. $\mathbf{C} 4.5$}

Algoritma C4.5 adalah salah satu teknik dari data mining yang berupa klasifikasi data.Tujuannya adalah untuk membuat model-model pendeskripsian kelas-kelas data yang penting.Algoritma ini adalah salah satu cabang pohon keputusan yang mirip seperti struktur pohon, berisi node internal (bukan daun), yang mendeskripsikan atribut-atribut, setiap cabang menggambarkan hasil dari atribut yang diuji, dan setiap daun menggambarkan kelas. Jika diuji dengan sejumlah data, misalnya $\mathrm{X}$ di mana kelas data $\mathrm{X}$ ini belum diketahui, maka pohon keputusan ini akan bekerja menelusuri data mulai dari akar sampai node dan setiap nilai dari atribut sesuai data X diuji apakah sesuai dengan aturan pohon keputusan, kemudian pohon keputusan akan memprediksi kelas dari tupel X [10].

Algoritma C4.5 dalam penelitian akan digunakan untuk mengklasifikasikan data akademik mahasiswa prodi Farmasi yang selanjutnya akan digunakan untuk memprediksi kelulusan tepat waktu. Hasil prediksi akan dijadikan dasar pengambilan kebijakan oleh pihak universitas untuk semakin mendorong para mahasiswa menyelesaikan studi mereka tepat waktu.

Tahap-tahap dalam membuat sebuah pohon keputusan dengan algoritma C4.5, adalah sebagai berikut [2]:

1. Menyiapkan data training/latih. Data training diambil dari data histori yang sudah terjadi sebelumnya dan dikelompokan ke dalam kelas-kelas tertentu.

2. Menentukan akar dari pohon. Akar akan diambil dari atribut yang terpilih, dengan cara menghitung nilai gain dari masing-masing atribut, nilai gain yang paling tinggi yang akan menjadi akar pertama. Sebelum menghitung gain dari atribut, hitung dahulu nilai entropy menggunakan persamaan 1 sebagai berikut:

$$
\operatorname{Entrophy}(s)=\sum_{i=1}^{n}-p i * \log _{2} p i
$$

Keterangan:

$\mathrm{S}$ : himpunan kasus

A : atribut

Techno Vol. 20, No. 2, Oktober 2019: 131-142 
n : jumlah partisi $S$

pi : proporsi dari Si terhadap S

3. Menentukan nilai gain dengan metode informasi gain:

$$
\operatorname{Gain}(S, A)=\operatorname{Entropy}(S)-\sum_{i=1}^{n} \frac{S i}{S} * \operatorname{Entropy}(S i)
$$

Keterangan :

$\mathrm{S}$ : himpunan kasus

A : atribut

$\mathrm{n} \quad$ : jumlah partisi atribut A

$|\mathrm{Si}|:$ jumlah kasus pada partisi ke-i

$|\mathrm{S}|$ : jumlah kasus dalam $\mathrm{S}$

4. Ulangi langkah ke-2 hingga semua kasus terpartisi.

5. Proses partisi pohon keputusan akan berhenti saat:

a. Semua kasus dalam node $\mathrm{N}$ mendapat kelas yang sama.

b. Tidak ada atribut di dalam kasus yang dipartisi lagi.

c. Tidak ada kasus di dalam cabang yang kosong.

\subsection{K-Nearest Neighbour (K-NN)}

Berbeda dari algoritam C4.5, algoritma K-Nearest Neighbour (K-NN) merupakan salah satu teknik klasifikasi data yang kuat dengan mencari kasus dengan menghitung kedekatan antara kasus baru dengan kasus lama melalui pencocokan bobot [8].

K-NN adalah metode algoritma supervised learning yang mendasarkan hasil klasifikasi pada kelas yang paling banyak muncul [7].

Alur dalam algoritma K-NN adalah:

1. Menentukan parameter K (jumlah tetangga paling dekat), Parameter K pada testing ditentukan berdasarkan nilai K optimum padasaat training.

2. Menghitung kuadrat jarak euclid (euclidean distance) masing-masing objek terhadap data sampel yang diberikan.

3. Mengurutkan objek-objek tersebut kedalam kelompok yang mempunyai jarak Euclidian terkeci

4. Mengumpulkan kategori Y ( klasifikasi nearest neighbour )

5. Dengan menggunakan kategori mayoritas, maka dapat hasil klasifikasi [6].

Dalam pendefinisian jarak antara x dan y, digunakan rumus jarak Euclidian pada persamaan (1) [7] berikut.

Keterangan :

$$
\mathrm{D}(\mathrm{x}, \mathrm{y})=\sqrt{\sum_{k}^{n}=1^{\left(X_{\text {training }}-Y_{\text {testing }}\right)^{2}}}
$$

Xtraining : data training ke- $i$,

Y testing : data testing,

$i \quad:$ record (baris) ke- $i$ dari table,

$n \quad$ : jumlah data training.

Seperti algoritma C4.5, algoritma K-NN digunakan untuk memprediksi klasifikasi data kelulusan tepat waktu mahasiswa prodi Farmasi, UMP. Kedua algoritma akan diuji efektifitasnya atau keakurasiannya dalam merepresentasikan data kelulusan tepat waktu dari 5 tahun kelulusan terakhir selanjutnya akan digunakan untuk menentukan strategi yang tepat dalam memperbaiki dan meningkatkan waktu kelulusan mahasiswa.

\subsection{Fitur Backward Selection/Elimination}

Metode backward, adalah suatu metode pemilihan variabel yang berpengaruh dalam analisa data dengan caramemasukkan semua variabel / prediktor, kemudian mengeliminasi satu persatu hingga tersiswa prediktor yang signifikan saja, yaitudengan melakukan pengujian terhadap parameter -parameternya dengan menggunakan partial $\mathrm{F}$ test. Nilai partial F-test (FL) terkecil dibandingkan dengan F0 table: 
- Jika FL < F0, maka X yang bersangkutan dikeluarkan dari model dan dilanjutkan dengan pembuatan model baru tanpa variable tersebut

- Jika FL>F0, maka proses dihentikan dan persamaan terakhir tersebut yang digunakan/dipilih

\section{METODE PENELITIAN}

\subsection{Metode Pengumpulan Data}

Tahap dalam penelitian ini adalah dengan pengumpulan data dilakukan melalui observasi langsung, yaitu mengamati basis data akademik mahasiswa prodi Farmasi UMP dari 5 tahun kelulusan terakhir untuk tujuan identifikasi masalah dan seleksi dataset yang akan diklasifikasikan ke dalam data training dan data testing. Selain itu juga melakukan studi pustaka untuk mendapatkan data sekunder berupa informasi yang penting untuk menjawab rumusan masalah.

\subsection{Metode Analisis Data}

Analisis data dalam penelitian ini akan dilakukan dengan menggunakan teknik klasifikasidata mining melalui algoritma C4.5 dan K-NN dengan menambahkan fitur backward selection. Atribut/variabel yang digunakan adalah: Jenis kelamin, Status Sekolah, Jurusan, NEM, nilai TPA, Indek prestasi semester (IPs), Indek prestasi komulatif (IPK), Jml SKS, dan Riwayat pembayaran SPP untuk mendapatkan keakuratan data prediksi kelulusan tepat waktu mahasiswa prodi Farmasi UMP TA 2010 sampai dengan 2019 (sekarang).

Dalam melakukan perbandingan analisa menggunakan algoritma $\mathrm{C} 4.5$ dan K-NN untuk menghasilkan keakuratan data, dilakukan beberapa cara, yaitu :

1. Melakukan uji data menggunakan beberapa pasang variabel yang berbeda pada masing-masing algoritma

2. Melakukan uji data dengan data training satu angkatan atau beberapa angkatan, atau seluruh angkatan

3. Melakukan uji data dengan hasil pemilihan variabel yang paling berpengaruh menggunakan fitur backward selection

4. Melakukan uji data dengan beberapa jumlah tetangga/ $\mathrm{N}$ pada algoritma K-NN

\subsection{Alur Penelitian}

Alur penelitian ini dilakukan dengan tahap-tahap sebagai berikut:

1. Pengumpulan data melalui observasi langsung yang bertujuan untuk identifikasi masalah dan studi pustaka

2. Pre-processing data yang dilakukan dengan menyeleksi dataset secara split datauntuk selanjutnya dilakukan mining yaitu dengan mengklasifikasikan dataset ke dalam data training dan data testing menggunakan algoritma klasifikasi dengan menambahkan fitur backward selectiondilengkapi atribut yang telah ditentukan untuk memperoleh klasifikasi data dan parameter evaluasi

3. Processing data dilakukan untuk mining klasifikasi data yang telah diperoleh dengan menambahkan fitur backwardselection dilengkapi atribut yang telah ditentukanmenggunakan algoritma C4.5 dan K-NN untuk mendapatkan optimatisasi kedua algoritma dalam memprediksi potensi kelulusan tepat waktu mahasiswa prodi Farmasi UMP.

4. Evaluation dilakukan untuk memperoleh optimalisasi perbandingan keakuratan kedua algoritma, keunggulan dan kelemahannya guna perumusan rekomendasi bagi pengambilan keputusan yang lebih strategik di masa mendatang, yaitu bagi peningkatan potensi kelulusan tepat waktu mahasiswa prodi Farmasi UMP. Pada tahap evaluasi ini dilakukan berbagai macam skenario untuk mendapatkan hasil yang mendekati keakuratan yang maksimal.

5. Recommendation dilakukan untuk memberikan pertimbangan terhadap prosessing data setelah dilakukan evaluasi dan mengetahui keakuratannya. 
Gambar 4 berikut ini adalah alur penelitian yang dimaksud.

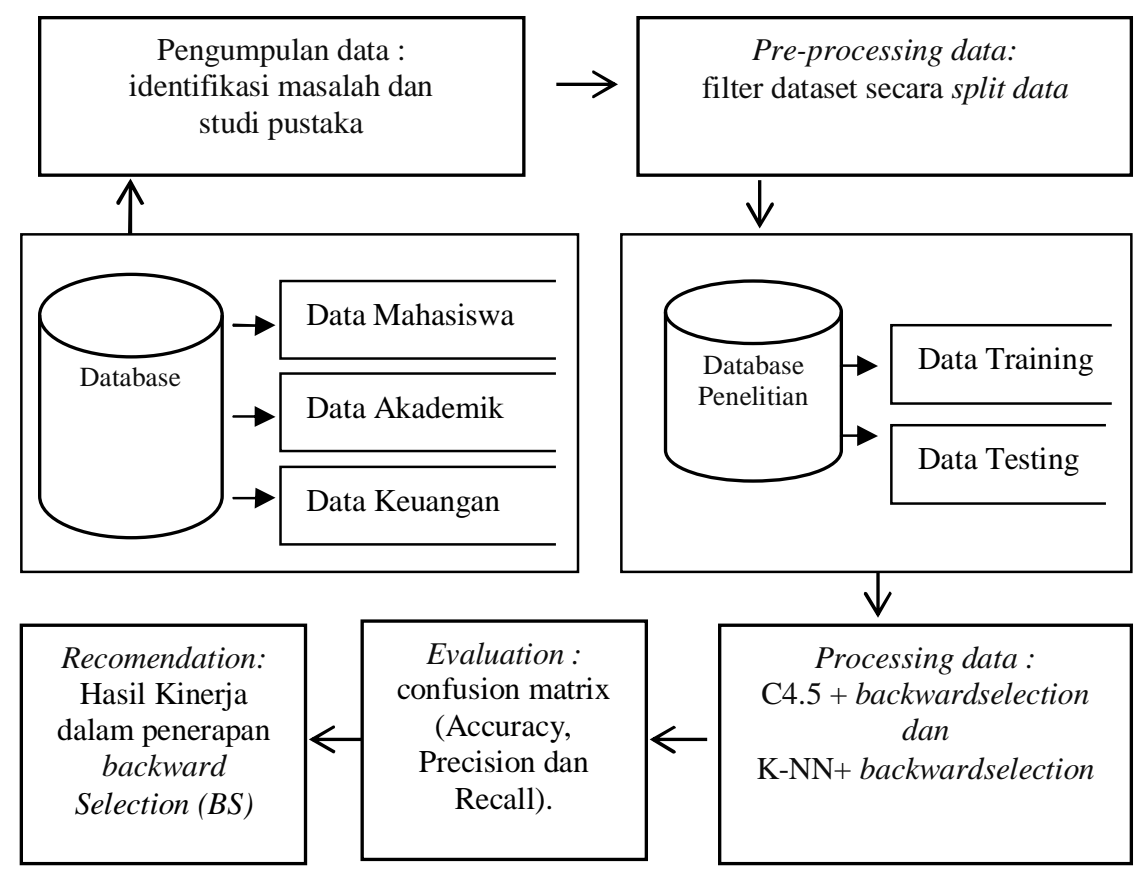

Gambar 4. Alur Penelitian yang dilakukan

\section{HASIL DAN PEMBAHASAN}

\subsection{Dataset Mahasiswa}

Setelah proses pengumpulan data dilakukan, proses klasifikasi diawali dengan penentuan dataset yang disimpan dalam format excel (*.xls) seperti pada gambar 5 berikut:

\begin{tabular}{|c|c|c|c|c|c|c|c|c|c|c|c|c|c|c|}
\hline 1 NIM & KEL STS SEKOLAH & JURUSAN & NEM & 1 TPA & SKS SMT 1 & 1 SKS SMT & 2 SKS SMT 3 & SPP SMT 3 & 3 SPP SMT 4 & 4 SPP SMT 5 & 5 SPP SMT 6 & 5PP SMT 7 & 7 SPP SMT 8 । & IPK SKS PREDIKAT KELULUSAN \\
\hline $21308010088 \mathrm{~L}$ & L SWASTA & IPS & 6 & 41 & 20 & 22 & 18 & 20141 & 20142 & 20151 & 20152 & 20161 & 20162 & 2,70 '146 TEPAT WAKTU \\
\hline 3) $1408010105 \mathrm{P}$ & P NEGERI & IPA & 6 & 61 & 20 & 22 & 20 & 20151 & 20152 & 20161 & 20162 & 20171 & 20172 & $3,34^{\prime 146}$ TEPAT WAKTU \\
\hline $44^{4} 1308010137$ & TL NEGGR & IPA & 7 & 44 & 20 & 22 & 18 & 2014 & 20142 & 2015 & 20152 & 20161 & 20162 & 275 196 TEPAT WAKTU \\
\hline 51408010189 L & NEGERI & IPA & 7 & 55 & 20 & 22 & 20 & 20151 & 20152 & 20161 & 20162 & 20171 & 20172 & 3,41 146 TEPAT WAKTU \\
\hline 6 1408010115 P & $\begin{array}{lll}5 & \text { N } \\
\text { NEGERI }\end{array}$ & IPA & 7 & 50 & 20 & 22 & 18 & 20151 & 20152 & 20161 & 20162 & 20171 & 20172 & 2,95 '146 TEPAT WAKTU \\
\hline 71408010124 P & P NEGERI & IPA & & 56 & 20 & 22 & 20 & 20151 & 20152 & 20161 & 20162 & 20171 & 20172 & 3,42 '146 TEPAT WAKTU \\
\hline $81308010041 \mathrm{P}$ & I P NEGERI & IPA & 8 & 46 & 20 & 22 & 18 & 20141 & 20142 & 20151 & 20152 & 20161 & 20162 & 3,01'146 TEPAT WAKTU \\
\hline 9 $1308010066 \mathrm{P}$ & 5 P $\quad$ NEGERI & FARMASI & 8 & 42 & 20 & 22 & 21 & 20141 & 20142 & 20151 & 20152 & 20161 & 20162 & 3,23'149 LAMBAT \\
\hline $101208010128 \mathrm{P}$ & P SWASTA & IPA & 8 & 54 & 20 & 22 & 21 & 20131 & 20132 & 20141 & 20142 & 20151 & 20152 & 3,00 147 TEPAT WAKTU \\
\hline $111308010054 \mathrm{~L}$ & L SWASTA & FARM & 8 & 44 & 20 & 22 & 21 & 20141 & 20142 & 20151 & 20152 & 20161 & 20162 & 2,95 146 TEPAT WAKTU \\
\hline $121108010061 \mathrm{P}$ & IP SWASTA & FARM & 25 & 98 & 20 & 22 & 21 & 20121 & 20122 & & 20132 & 20141 & 20142 & $3.38^{\prime} 147$ TEPAT WAKTU \\
\hline $131008010149 \mathrm{P}$ & P SWASTA & FARM & 26 & 106 & 20 & 20 & 21 & 20111 & 20112 & 20121 & 20122 & 20131 & 20132 & 3.32' 147 TEPAT WAKTU \\
\hline $141108010153 \mathrm{P}$ & P SWASTA & FARMASI & 32 & 95 & 20 & 18 & 18 & 20121 & 20122 & 20131 & 20132 & 20141 & 20142 & 2,53 147 LAMBAT \\
\hline $151108010100 \mathrm{p}$ & P SWASTA & FARMASI & 33 & 92 & 20 & 18 & 15 & 20121 & 20122 & 20131 & 20132 & 20141 & 20142 & $2,37^{\prime} 147$ LAMBAT \\
\hline $161108010090 \mathrm{P}$ & P SWASTA & FARM & 33 & 98 & 20 & 22 & 21 & 20121 & 20122 & 20131 & 20132 & 20141 & 20142 & 3.35 148 TEPAT WAKTU \\
\hline $17^{\prime} 1108010121 \mathrm{P}$ & IASTA & FARM & 34 & 97 & 20 & 22 & 21 & 20121 & 20122 & 20131 & 20132 & 20141 & 20142 & 3.31 147 TEPAT WAKTU \\
\hline $181208010054 \mathrm{P}$ & P SWASTA & FARMASI & 34 & 45 & 20 & 22 & 21 & 20131 & 20132 & 20141 & 20142 & 20151 & 20152 & 2,89 147 TEPAT WAKTU \\
\hline $191008010043 \mathrm{~L}$ & L N NEGERI & $\begin{array}{l}\text { FARSASI } \\
\text { IPS }\end{array}$ & $\begin{array}{l}44 \\
40\end{array}$ & 95 & 20 & 15 & 21 & 20111 & $\frac{20132}{20112}$ & 20121 & 20122 & 20131 & 20132 & $2.40^{\circ} 147$ LAMBAT \\
\hline $201108010060 \mathrm{P}$ & P SWASTA & FARMA & 40 & 94 & 20 & 15 & 18 & 20121 & 20122 & 20131 & 20132 & 20141 & 20142 & 2,32 147 LAMBAT \\
\hline $211208010152 \mathrm{P}$ & $2 \mathrm{P}$ NEGERI & IPA & 41 & 34 & 20 & 22 & 21 & 20131 & 20132 & 20141 & 20142 & 20151 & 20152 & 3,11'147 TEPAT WAKTU \\
\hline $221108010083 \mathrm{P}$ & P NEGERI & IPA & 41 & 95 & 20 & 22 & 18 & 20121 & 20122 & 20131 & 20132 & 20141 & 20142 & 2.50148 TEPAT WAKTU \\
\hline 231208010123 L & 3 L NEGERI & IPA & 42 & 50 & 20 & 19 & 18 & 20131 & 20132 & 20141 & 20142 & 20151 & 20152 & 2,44"147 LAMBAT \\
\hline 241208010102 P & $2 \mathrm{P}$ NEGERI & IPA & 42 & 54 & 20 & 20 & 18 & 20131 & 20132 & 20141 & 201 & 20151 & 2015 & 2,59'147 LAMBAT \\
\hline $251108010068 \mathrm{P}$ & P SWASTA & FARMASI & 44 & 103 & 20 & 22 & 21 & 20121 & 20122 & 20131 & 20132 & 20141 & 20142 & 3.70 147 TEPAT WAKTU \\
\hline
\end{tabular}

Gambar 5. Potongan Data Status Mahasiswa

Variabel yang digunakan untuk proses data dan tipe data attribut dan label pada data indikator dataset mahasiswa dalam penelitian ini dapat dijabarkan seperti pada table 1 berikut:

Tabel 1. Pembagian Variabel, Atribut, Kelas dan Tipe Data

\begin{tabular}{clll}
\hline Variabel & \multicolumn{1}{c}{ Nama Atribut } & \multicolumn{1}{c}{ Kelas Data } & \multicolumn{1}{c}{ Tipe Data } \\
\hline V1 & NIM & Nomor Induk Mahasiswa & Character \\
V2 & Jenis Kelamin & Laki-laki ; Perempuan & Character \\
V3 & Status Sekolah Asal & Negeri ; Swasta & Character \\
V4 & Jurusan & Juruan SLTA & Character \\
V5 & NEM & Nilai Ebtanas Murni & Numeric \\
V6 & Nilai TPA & Nilai Tes Potensi Akademik & Numeric \\
V7 & Indek Prestasi Smt 1 & 0 s/d 4,00 & Numeric
\end{tabular}

Prediksi Kelulusan Tepat Waktu Menggunakan Metode $C 4.5$ dan $K-N N$ Studi Kasus : Mahasiswa Program Studi S1 Ilmu Farmasi, Fakultas Farmasi Universitas Muhammadiyah Purwokerto (Eko Purwanto) 


\begin{tabular}{|c|c|c|c|}
\hline V8 & Indek Prestasi Smt 2 & $0 \mathrm{~s} / \mathrm{d} 4,00$ & Numeric \\
\hline V9 & Indek Prestasi Smt 3 & $0 \mathrm{~s} / \mathrm{d} 4,00$ & Numeric \\
\hline V10 & Indek Prestasi Smt 4 & $0 \mathrm{~s} / \mathrm{d} 4,00$ & Numeric \\
\hline V11 & Indek Prestasi Smt 5 & $0 \mathrm{~s} / \mathrm{d} 4,00$ & Numeric \\
\hline V12 & Indek Prestasi Smt 6 & $0 \mathrm{~s} / \mathrm{d} 4,00$ & Numeric \\
\hline V13 & Indek Prestasi Smt 7 & $0 \mathrm{~s} / \mathrm{d} 4,00$ & Numeric \\
\hline V14 & Indek Prestasi Smt 8 & $0 \mathrm{~s} / \mathrm{d} 4,00$ & Numeric \\
\hline V15 & Registrasi/Aktif Smt 1 & Aktif ; Tidak Aktif ; Lulus & Character \\
\hline V16 & Registrasi/Aktif Smt 2 & Aktif ; Tidak Aktif ; Lulus & Character \\
\hline V17 & Registrasi/Aktif Smt 3 & Aktif ; Tidak Aktif ; Lulus & Character \\
\hline V18 & Registrasi/Aktif Smt 4 & Aktif ; Tidak Aktif ; Lulus & Character \\
\hline V19 & Registrasi/Aktif Smt 5 & Aktif ; Tidak Aktif ; Lulus & Character \\
\hline V20 & Registrasi/Aktif Smt 6 & Aktif ; Tidak Aktif ; Lulus & Character \\
\hline V21 & Registrasi/Aktif Smt 7 & Aktif ; Tidak Aktif ; Lulus & Character \\
\hline V22 & Registrasi/Aktif Smt 8 & Aktif ; Tidak Aktif ; Lulus & Character \\
\hline $\mathrm{V} 23$ & SKS & $0 \mathrm{~s} / \mathrm{d} 150$ & Numeric \\
\hline $\mathrm{V} 24$ & IPK & $0 \mathrm{~s} / \mathrm{d} 4,00$ & Numeric \\
\hline
\end{tabular}

\subsection{Implementasi K-NN}

Dari jumlah data lulusan mulai angkatan 2010-2015 sebanyak 719, ditentukan untuk data latih/training angkatan 2010-2013 sebanyak 543 dan untuk data uji/test angkatan 2014-2015 sebanyak 176

Contoh proses perhitungan menggunakan algoritma K-NN menggunakan excel dengan menentukan jumlah tetangga(N) antara $1 \mathrm{~s} / \mathrm{d} 21$ ditunjukan pada gambar 6 berikut :

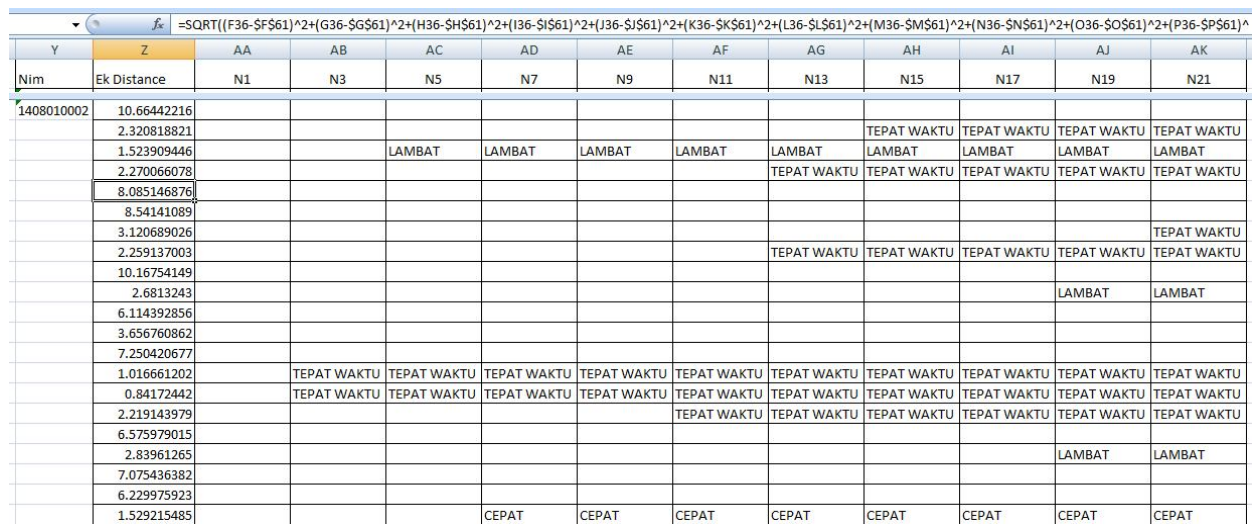

Gambar 6. Potongan proses perhitungan menggunakan algoritma K-NN

\subsection{Implementasi $\mathbf{C} 4.5$}

Pada implementasi C4.5, dilakukan proses klasifikasi terhadap atribut dan jumlah nilai pada masing-masing atributnya seperti pada Tabel 2, selanjutnya hitunglah enteropi dan Gainnya menggunakan rumus Enteropi dan Gain seperti pada rumus persamaan ke (1) dan (2).

Tabel 2. Menghitung Jumlah kasus setiap atribut dan menghitung Enteropi dan Gain masing-masing atribut pada node pertama.

\begin{tabular}{|c|c|c|c|c|c|c|c|}
\hline Atribut & Nilai & $\begin{array}{c}\text { Jml } \\
\text { Kasus }\end{array}$ & Cepat & $\begin{array}{c}\text { Tepat } \\
\text { Waktu }\end{array}$ & Lambat & Entropi & Gain \\
\hline \multirow[t]{4}{*}{$\begin{array}{l}\text { Jenis } \\
\text { Kelamin }\end{array}$} & & & & & & & \multirow[t]{4}{*}{0.030536835} \\
\hline & Laki-laki & 124 & 9 & 54 & 61 & 1.30042028 & \\
\hline & Perempuan & 419 & 15 & 283 & 121 & 1.07184678 & \\
\hline & Total & 543 & 24 & 337 & 182 & 1.15458088 & \\
\hline \multirow[t]{2}{*}{$\begin{array}{l}\text { Status } \\
\text { Sekolah } \\
\text { Asal }\end{array}$} & & & & & & & \multirow[t]{2}{*}{0.006038652} \\
\hline & $\begin{array}{l}\text { Negeri } \\
\text { Swasta } \\
\text { Total }\end{array}$ & $\begin{array}{l}344 \\
199 \\
543\end{array}$ & $\begin{array}{c}17 \\
7 \\
24\end{array}$ & $\begin{array}{l}202 \\
135 \\
337\end{array}$ & $\begin{array}{c}125 \\
57 \\
182\end{array}$ & $\begin{array}{l}1.19612341 \\
1.06629135 \\
1.15458088\end{array}$ & \\
\hline Jurusan & $\begin{array}{l}\text { IPA } \\
\text { IPS } \\
\text { Farmasi }\end{array}$ & $\begin{array}{c}346 \\
27 \\
161 \\
\end{array}$ & $\begin{array}{c}19 \\
0 \\
5 \\
\end{array}$ & $\begin{array}{c}215 \\
12 \\
105 \\
\end{array}$ & $\begin{array}{c}112 \\
15 \\
51 \\
\end{array}$ & $\begin{array}{c}1.18319517 \\
0 \\
1.08309631 \\
\end{array}$ & 0.079508994 \\
\hline
\end{tabular}

Techno Vol. 20, No. 2, Oktober 2019: 131-142 


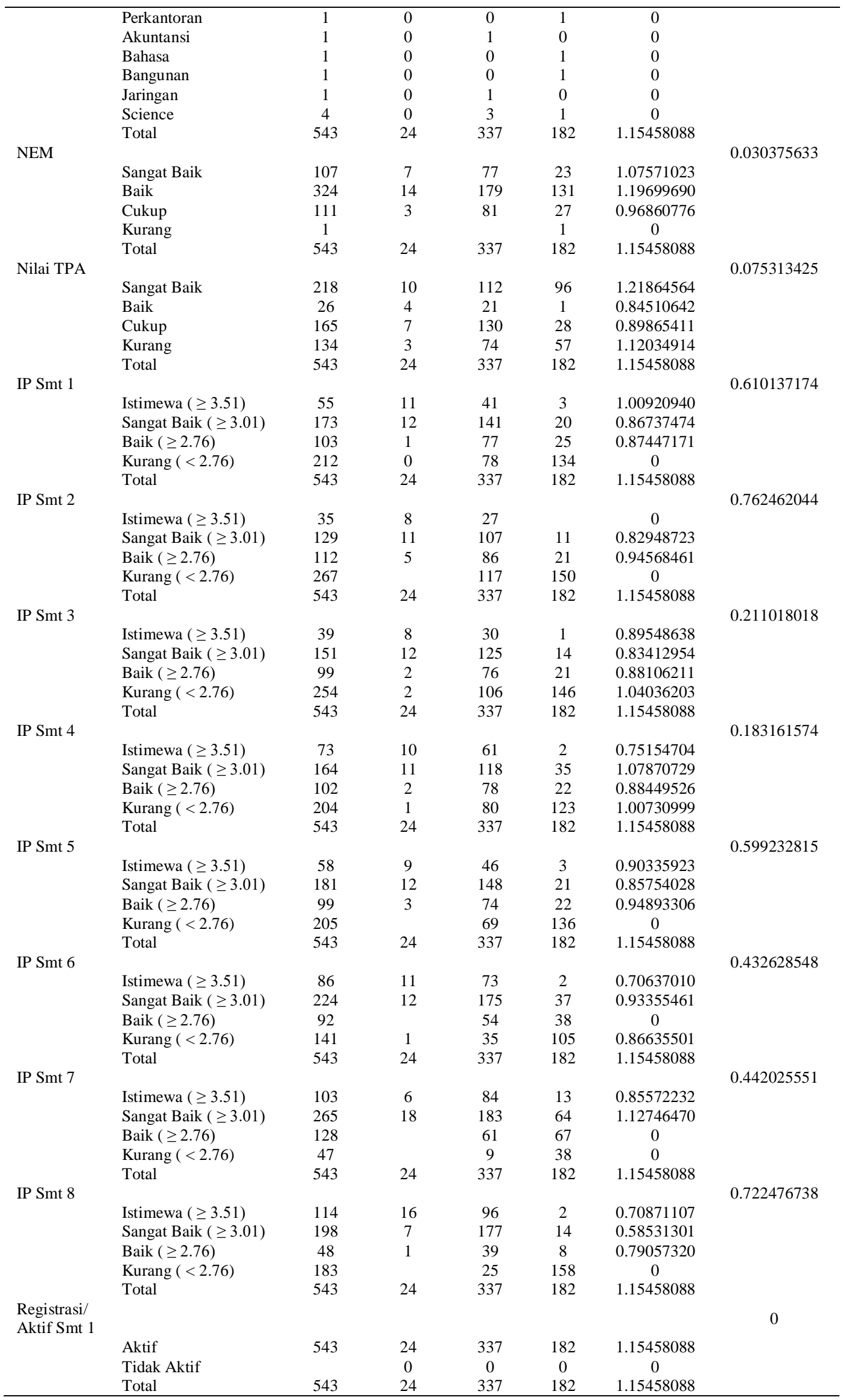

Prediksi Kelulusan Tepat Waktu Menggunakan Metode $C 4.5$ dan $K$-NN Studi Kasus : Mahasiswa Program Studi S1 Ilmu Farmasi, Fakultas Farmasi Universitas Muhammadiyah Purwokerto (Eko Purwanto) 


\begin{tabular}{|c|c|c|c|c|c|c|c|}
\hline \multirow[t]{4}{*}{$\begin{array}{l}\text { Registrasi/ } \\
\text { Aktif Smt } 2\end{array}$} & & & & & & & 0 \\
\hline & Aktif & 543 & 24 & 337 & 182 & 1.15458088 & \multirow{7}{*}{0} \\
\hline & Tidak Aktif & & & & & 0 & \\
\hline & Total & 543 & 24 & 337 & 182 & 1.15458088 & \\
\hline \multirow[t]{4}{*}{$\begin{array}{l}\text { Registrasi/ } \\
\text { Aktif Smt } 3\end{array}$} & & & & & & & \\
\hline & Aktif & 543 & 24 & 337 & 182 & 1.15458088 & \\
\hline & Tidak Aktif & & & & & 0.00000000 & \\
\hline & Total & 543 & 24 & 337 & 182 & 1.15458088 & \\
\hline \multirow{4}{*}{$\begin{array}{l}\text { Registrasi/ } \\
\text { Aktif Smt } 4\end{array}$} & & & & & & & \multirow[t]{4}{*}{0} \\
\hline & Aktif & 543 & 24 & 337 & 182 & 1.15458088 & \\
\hline & Tidak Aktif & & & & & 0 & \\
\hline & Total & 543 & 24 & 337 & 182 & 1.15458088 & \\
\hline \multirow{4}{*}{$\begin{array}{l}\text { Registrasi/ } \\
\text { Aktif Smt } 5\end{array}$} & & & & & & & \multirow[t]{4}{*}{0} \\
\hline & Aktif & 543 & 24 & 337 & 182 & 1.15458088 & \\
\hline & Tidak Aktif & & & & & 0 & \\
\hline & Total & 543 & 24 & 337 & 182 & 1.15458088 & \\
\hline \multirow[t]{4}{*}{$\begin{array}{l}\text { Registrasi/ } \\
\text { Aktif Smt } 6\end{array}$} & & & & & & & \multirow[t]{4}{*}{0} \\
\hline & Aktif & 543 & 24 & 337 & 182 & 1.15458088 & \\
\hline & Tidak Aktif & 0 & 0 & 0 & 0 & 0 & \\
\hline & Total & 543 & 24 & 337 & 182 & 1.15458088 & \\
\hline \multirow[t]{5}{*}{$\begin{array}{l}\text { Registrasi/ } \\
\text { Aktif Smt } 7\end{array}$} & & & & & & & \multirow[t]{5}{*}{0.008340698} \\
\hline & Aktif & 542 & 23 & 337 & 182 & 1.14835502 & \\
\hline & Tidak Aktif & & & & & 0 & \\
\hline & Lulus & 1 & 1 & & & 0 & \\
\hline & Total & 543 & 24 & 337 & 182 & 1.15458088 & \\
\hline \multirow[t]{5}{*}{$\begin{array}{l}\text { Registrasi/ } \\
\text { Aktif Smt } 8\end{array}$} & & & & & & & \multirow[t]{5}{*}{0.034048192} \\
\hline & Aktif & 539 & 20 & 337 & 182 & 1.12884833 & \\
\hline & Tidak Aktif & & & & & 0 & \\
\hline & Lulus & 4 & 4 & & & 0 & \\
\hline & Total & 543 & 24 & 337 & 182 & 1.15458088 & \\
\hline \multirow[t]{4}{*}{ SKS } & & & & & & & \multirow[t]{4}{*}{0.007316331} \\
\hline & $>=147$ & 470 & 18 & 300 & 152 & 1.12036963 & \\
\hline & $>=144$ & 73 & 6 & 37 & 30 & 1.32042364 & \\
\hline & Total & 543 & 24 & 337 & 182 & 1.15458088 & \\
\hline \multirow[t]{6}{*}{ IPK } & & & & & & & \multirow[t]{6}{*}{0.695028759} \\
\hline & Istimewa $(\geq 3.51)$ & 57 & 12 & 43 & 2 & 0.94957537 & \\
\hline & Sangat Baik $(\geq 3.01)$ & 235 & 12 & 193 & 30 & 0.83153620 & \\
\hline & Baik $(\geq 2.76)$ & 122 & & 72 & 50 & 0 & \\
\hline & Kurang $(<2.76)$ & 129 & & 29 & 100 & 0 & \\
\hline & Total & 543 & 24 & 337 & 182 & 1.15458088 & \\
\hline
\end{tabular}

Dalam menentukan entropy dan gain prosesnya akan berhenti sampai tidak ada atribut lainnya yang dapat digunakan untuk mempartisi sampai lebih lanjut. Dan selanjutnya menentukan pohon keputusannya berdasarkan nilai gain tertinggi.

\subsection{Analisa Hasil}

Dari perhitungan K-NN dan C4.5, diperoleh keakuratan data yang ditunjukan pada tabel 3 sebagai berikut :

Tabel 3. Keakuratan data menggunakan Algoritma K-NN dan C4.5

\begin{tabular}{cccc}
\hline Algoritma & Jumlah Data Training & Jumlah Data Testing & Keakuratan \\
\hline K-NN & 543 & 76 & $82,26 \%$ \\
C4.5 & 543 & 76 & $80,68 \%$ \\
\hline
\end{tabular}

Untuk meningkatkan hasil kekauratan data, dilakukan penambahan seleksi atribut yang paling menentukan dan membuang atribut yang tidak berperangaruh menggunakan seleksi fitur Backward eliminiation dengan regresi linear. Penentuan variabel yang berpengaruh menggunakan aplikasi statistik regresi linear melalui tahap atau model 9 proses. Proses pertama ditunjukan pada tabel 4 berikut : 
Tabel 4. Korelasi antar variabel dalam model 1

\begin{tabular}{|c|c|c|c|c|c|c|c|c|}
\hline \multicolumn{9}{|c|}{ Coefficients $^{\Xi}$} \\
\hline & & \multicolumn{2}{|c|}{ Unstandardized Coefficients } & $\begin{array}{l}\text { Standardized } \\
\text { Coefficients }\end{array}$ & \multirow[b]{2}{*}{$t$} & \multirow[b]{2}{*}{ Siq. } & \multicolumn{2}{|c|}{$95.0 \%$ Confidence Interval for $\mathrm{B}$} \\
\hline \multicolumn{2}{|c|}{ Madel } & $\mathrm{B}$ & Std. Error & Beta & & & Lower Bound & Upper Bound \\
\hline 1 & (Constant) & 22.282 & 4.644 & & 4.798 & .000 & 13.158 & 31.405 \\
\hline & KE1 & .038 & .057 & .022 & .671 & .503 & -.074 & .150 \\
\hline & STS SEKOLAH & .127 & .056 & .083 & 2.285 & .023 & .018 & .237 \\
\hline & JURUSAN & .011 & .036 & .011 & .296 & .767 & -.060 & .082 \\
\hline & NEM & .012 & .028 & .014 & .412 & .681 & -.044 & .067 \\
\hline & TPA & .005 & .001 & .160 & 4.300 & .000 & .003 & .008 \\
\hline & IPS SMT 1 & .014 & .113 & .009 & .120 & .905 & -.208 & .235 \\
\hline & IPS SMT 2 & -.186 & .109 & -.129 & -1.715 & .087 & -.400 & .027 \\
\hline & IPS SMT 3 & .039 & .121 & .025 & .319 & .750 & -.199 & .277 \\
\hline & IPS SMT 4 & .017 & .107 & .012 & .162 & .871 & -.193 & .228 \\
\hline & IPS SMT 5 & -.408 & .108 & -.276 & -3.770 & .000 & -.620 & -.195 \\
\hline & IPS SMT 6 & .021 & .087 & .014 & .245 & .807 & -.150 & .193 \\
\hline & IPS SMT 7 & -.302 & .083 & -.159 & -3.640 & .000 & -.464 & -.139 \\
\hline & IPS SMT 8 & -.394 & .031 & -.513 & -12.551 & .000 & -.456 & -.332 \\
\hline & SPP SMT 7 & -1.385 & .622 & -.080 & -2.226 & .026 & -2.607 & -.163 \\
\hline & SPP SMT 8 & -.247 & .318 & -.028 & -.776 & .438 & -.872 & .378 \\
\hline & IPK & .540 & .337 & .265 & 1.601 & .110 & -.123 & 1.202 \\
\hline & SKS & -.106 & .031 & -.111 & -3.392 & .001 & -.168 & -.045 \\
\hline
\end{tabular}

Pada model pertama (1), ditunjukan dengan penghilangan/penghapusan beberapa variabel/atribut yang tidak berpengaruh karena datanya bersifat homogen. Selanjutnya potongan proses model ke 9 (terakhir) ditunjukan pada tabel 5 berikut :

Tabel 5. Korelasi antar variabel dalam model 9

\begin{tabular}{|c|c|c|c|c|c|c|c|c|}
\hline \multirow[t]{10}{*}{9} & (Constant) & 22.275 & 4.455 & & 5.000 & .000 & 13.523 & 31.027 \\
\hline & STS SEKOLAH & .134 & .048 & .087 & 2.796 & .005 & .040 & .227 \\
\hline & TPA & .006 & .001 & .169 & 5.375 & .000 & .004 & .008 \\
\hline & IPS SMT 2 & -.167 & .101 & -.116 & -1.659 & .098 & -.366 & .031 \\
\hline & IPS SMT 5 & -.401 & .101 & -.271 & -3.969 & .000 & -600 & -.203 \\
\hline & IPS SMT 7 & -.296 & .081 & -.157 & -3.671 & .000 & -.454 & -.138 \\
\hline & IPS SMT 8 & -.394 & .031 & -.512 & -12.800 & .000 & -.454 & -.333 \\
\hline & SPP SMT 7 & -1.673 & .535 & -.097 & -3.127 & .002 & -2.723 & -.622 \\
\hline & IPK & .600 & .220 & .294 & 2.722 & .007 & .167 & 1.032 \\
\hline & SKS & -.105 & .030 & -.110 & -3.479 & .001 & -.165 & -.046 \\
\hline
\end{tabular}

Dalam model ke 9, diperoleh variabel-variabel yang lebih berpengaruh terhadap proses pengolahan data prediksi kelulusan. Selanjutnya perhitungan ulang algoritma K-NN dan C4.5 meggunakan variabel/atribut tersebut, dan menghasilkan kekauratan data yang ditunjukan pada tabel 6 berikut.

Tabel 6. Keakuratan data menggunakan Algoritma K-NN+Backward Elimination dan C4.5+Backward Elimination

\begin{tabular}{cccc}
\hline Algoritma & Jumlah Data Training & Jumlah Data Testing & Kekauratan \\
\hline $\begin{array}{c}\text { K-NN + Backward } \\
\text { Elimination }\end{array}$ & 543 & 76 & $89,14 \%$ \\
$\begin{array}{c}\text { C4.5 + Backward } \\
\text { Elimination }\end{array}$ & 543 & 76 & $84,75 \%$ \\
\hline
\end{tabular}

\section{KESIMPULAN}

Pengujian data prediksi kelulusan tepat waktu menggunakan perbandingan algoritma K-NN dan C4.5 menghasilkan data keakuratan yang tinggi diatas $80 \%$. Keakuratan data dapat ditingkatkan dengan menambahkan fitur Backward Selection/Elimination sehingga meningkatan keakuratan data pada penelitian ini. Dengan keakuratan yang tinggi, diharapkan metode ini dapat membantu menentukan arah kebijakan pada institusi dalam rangka meningkatkan mutu kelulusan dengan cepat atau tepat waktu.

\section{DAFTAR PUSTAKA.}

[1] Aggarwal, Charu J. 2015. Data Mining: The Textbook. Springer. New York.

[2] Kusrini dan Luthfi, E. T., 2009. Algoritma Data Mining. Yogyakarta : Penerbit Andi. 
[3] Han, Jiawei, Kamber, Micheline, dan Pei, Jian. 2012. Data Mining: Concepts and Techniques.Edisi ketiga.Morgan Kaufmann Publishers. USA.

[4] Witten, Ian H. dan Frank, Eibe. 2005. Data Mining: Practical Machine Learning Tools and Techniques.Edisi kedua.Morgan Kaufmann Publishers. San Fransisco.

[5] Atma, Yeyen Dwi dan Setyanto, Arief. 2018. "Perbandingan Algoritma C4.5 Dan K-NN Dalam Identifikasi Mahasiswa Berpotensi Drop Out”. Jurnal Metik. Vol. 2 No.2.hal.31-37.

[6] Mustafa, M. S. and Simpen, I. W., 2014."Perancangan Aplikasi Prediksi Kelulusan Tepat Waktu Bagi Mahasiswa Baru Dengan Teknik Data Mining (Studi Kasus: Data Akademik Mahasiswa STMIK Dipanegara Makassar)”.Citec J.Vol. 1. hal. 270-281.

[7] Mustakim,Giantika O, 2016 “Algoritma K-Nearest Neighbor Classification Sebagai Sistem Prediksi Predikat Prestasi Mahasiswa.”J. Sains dan Teknol. Ind. Vol. 13. No. 2.hal.195-202.

[8] Ndaumanu, R. I. Arief, M. R., dan Kusrini. 2014. "Analisis Prediksi Tingkat Pengunduran Diri Mahasiswa dengan Metode K-Nearest Neighbor,” Jatisi. Vol. 1, No. 1.hal.1-15.

[9] Putri, Ratna Puspita Sari dan Waspada, Indra.Juni 2018."Penerapan Algoritma C4.5 pada Aplikasi Prediksi Kelulusan Mahasiswa Prodi Informatik”.Khazanah Informatika, Vol. 4 No. 1, Juni, 2018.hal.1-7.

[10] Risnawati.Juni 2018 “Analisis Kelulusan Mahasiswa Menggunakan Algoritma C.45”. Jurnal Mantik Penusa. Volume 2, No. 1.hal.71-76.

[11] Rohmawan, Eko Prasetiyo. April 2018. "Prediksi Kelulusan Mahasiswa Tepat Waktu Menggunakan Metode Decision Tree dan Artificial Neural Network”.Jurnal Ilmiah Matrik Vol.20 No.1. 